\title{
The Role of Exchange Rates in the Stock Price Development of Chemical Companies in the Visegrad Four Countries ${ }^{1}$
}

\author{
Jana Šimáková \\ Ph.D., Assistant Professor, Silesian University in Opava, School of Business \\ Administration in Karviná, Department of Finance and Accounting, Karviná \\ Czech Republic, e-mail: simakova@opf.slu.cz
}

\author{
Nikola Rusková \\ Silesian University in Opava, School of Business Administration in Karviná \\ Department of Finance and Accounting, Karviná, Czech Republic \\ e-mail: nikola.ruskova@seznam.cz
}

\section{Abstract}

The aim of the paper is to evaluate the effect of exchange rates on the stock prices of companies in the chemical industry listed on the stock exchanges in the Visegrad Four countries. The empirical analysis was performed from September 2003 to June 2016 on companies from the petrochemical and pharmaceutical industry. The effect of the exchange rate on stock prices is analyzed using Jorion's approach on monthly data. In contrast to the selected petrochemical companies, the pharmaceutical companies did not use any hedging instruments in the tested period. The effect of the exchange rate on the stock price was proved only in the case of companies from the pharmaceutical industry. This suggests that exchange rate risk could be eliminated by using hedging instruments.

Keywords: exchange rate, firm value, exchange rate exposure, Jorion's model, chemical industry

JEL: F31, G12

1 The publication of this paper was supported by the Student Grant System of the Silesian University [project SGS/23/2016] and by the Ministry of Education, Youth and Sports within the Institutional Support for Long-term Development of a Research Organization in 2019. The support is gratefully acknowledged. 


\section{Introduction}

The liberalization of the financial markets in combination with the implementation of more flexible exchange rate regimes means that exchange rate movements have become a crucial feature of the international economic environment. As Nieh and Wang $(2005$, p. 55) argue, these developments require adjustments in a company's costs and profits, which affects overall profitability and increases the exchange exposure of enterprises and financial institutions. Exchange rate sensitivity has an impact on a company's value since its future cash flow is influenced by fluctuations in the exchange rates. In general, while the value of an exporting firm is more likely to decrease based upon the appreciation of the domestic currency, the value of an importing firm tends to increase (Akay and Cifter 2014, p. 426), and vice versa in the case of the domestic currency's depreciation. However, the total effect is affected not only by the direction of the exchange rate movement, but even its uncertainty and the nature of the company determine the whole exchange rate risk.

Many empirical studies provide evidence about the negative impact of uncertainty regarding the development of the exchange rate on a company's cash flow, and thus its market value (e.g. Muller and Verschoor 2006, pp. 495-518). Some studies suggest that foreign revenues are positively linked to exchange rate exposure and in the short term currency depreciation could negatively affect the market value of the company (e.g. He and $\mathrm{Ng}$ 1998, p. 751). However, there are even studies that do not show any statistically significant relationship between the value of a company and exchange rates (e.g. Stavárek 2005, pp. 141-161). Hence, the effects of the exchange rates on the value of the company are still open to further research.

Considering the fact that more than $95 \%$ of the facilities and devices being used are produced by the components made by thechemical industry through a series of simple or complex processes of converting production inputs such as gas and oil (Abbasi et al. 2015, p. 1171), this industry has found a special importance in the economy of the Visegrad Four (V4) countries and is seen as one of the strategic sectors. Therefore, the aim of the paper is to evaluate the effect of exchange rates on the stock prices of companies in the chemical industry listed on the stock exchanges in the V4 countries. This group of countries includes the Czech Republic (CZ), Hungary (HU), Poland (PL) and Slovakia (SK). Three decades ago, these countries started a transformation to become market economies, and today they are characterized as open economies. The transformation process influenced their economic structure, involvement in international economic activities, capital markets, and exchange rates regime as well. This study contributes to the current empirical evidence by showing differences in the relationship between the exchange rate and the stock prices of companies operating in an open economy with strong connections to the EU and the euro area. The topicality of this research is underlined by the fact that Slovakia is already a member of the Eurozone, firms in Hungary have a huge portion of debt denominated in foreign currency, and the Bank Board of the Czech National Bank abandoned exchange rate interventions as a monetary policy instrument in April 2017. Exchange rate effects seem to be, therefore, important determinants of a firm's value in the sample countries. 
In order to estimate these effects, the paper applies Jorion's model (1990, pp. 331345). In order to be able to compare the results between countries, the analysis includes only companies from the chemical industry, namely the petrochemical and pharmaceutical industry. The selected industry has a significant position in the V4 economies and is represented by companies listed in the V4 main stock exchanges. The sample period is from September 2003 to June 2016. This paper fully addresses the criticism of existing studies on the determinants of firms' exposure to exchange rate movements, which tend to use cross-sectional analysis, ignoring the temporal dimension of both dependent and explanatory variables. Therefore, this study uses Jorion's model and a combination of ordinary least squares (OLS) regression and the panel data approach, which pools data across firms and time, in order to improve estimation efficiency.

\section{Review of Relevant Literature}

The theoretical relationship between a company's performance and the development of exchange rates has led to numerous empirical studies. Early empirical research revealed almost no effect of exchange rates on companies' stock prices (e.g. Jorion 1990, p. 343). Furthermore, early empirical studies on exchange rate effects on stock prices provided weak statistical evidence (Akay and Cifter 2014, pp. 426-434). Recent studies focus more on the data, but also on the methodological and technical issues of model settings. Hence, more recent research provides more statistically significant but ambiguous results.

We can find many studies concerning the effects of exchange rates on stock prices, but only a few of them concern the V4 countries. The overview of these studies can be seen in Table 1. Stavárek (2005, pp. 141-161) investigated the relationship between exchange rates and stock markets by applying Granger causality in four old European Union (EU) member countries, four new EU member countries and the USA. On the one hand, there was no significant long-term relationship between stock prices and changes in the exchange rate in the research period 1970-1992. On the other hand, in the period 1993-2003, the causal relationship was statistically significant in the long-term for the old member states. However, the conclusions about a lack of relationship between exchange rates and stock prices in the tested V4 countries remained the same. Akel (2014, pp. 1-13) investigated the relationship between exchange rates and stock prices in nine transition economies (Bulgaria, Czech Republic, Estonia, Hungary, Lithuania, Latvia, Poland, Romania and Russian Federation) in the period 1995-2011. He determined that there are no causal relationships except for the case of the Russian Federation when using linear Granger causality; the results for the V4 countries are the same as in the case of Stavárek (2005, p. 158). However, changing the methodology to non-linear Granger causality revealed statistically significant causality between the relevant exchange rates and stock prices. 
Table 1. Studies on the Relationship between Exchange Rates and Stock Value in V4

\begin{tabular}{|c|c|c|c|c|}
\hline Study & Methods & Period & V4 Country & Relationship \\
\hline $\begin{array}{l}\text { Stavárek } \\
\text { (2005, pp. 141-161) }\end{array}$ & $\begin{array}{l}\text { Granger } \\
\text { causality }\end{array}$ & $\begin{array}{l}1970-1992 \\
1993-2003\end{array}$ & $\mathrm{CZ}, \mathrm{HU}, \mathrm{PL}, \mathrm{SK}$ & NO \\
\hline $\begin{array}{l}\text { Stavárek } \\
\text { and Tomanová } \\
(2014, \text { pp. 882-890) }\end{array}$ & Jorion's model & 2003-2014 & $C Z$ & $54 \%$ of firms \\
\hline $\begin{array}{l}\text { Tomanová (2014, } \\
\text { pp. 47-65) }\end{array}$ & Jorion's model & $\begin{array}{l}2000-2006 \\
2007-2014\end{array}$ & $\mathrm{HU}$ & $4.5 \%$ and $18.4 \%$ of firms \\
\hline Akel (2014, pp. 1-13) & $\begin{array}{l}\text { Linear } \\
\text { Causality }\end{array}$ & $1995-2011$ & $\mathrm{CZ}, \mathrm{HU}, \mathrm{PL}$ & NO \\
\hline $\begin{array}{l}\text { Akel (2014, } \\
\text { pp. 1-13) }\end{array}$ & $\begin{array}{l}\text { Non-linear } \\
\text { Causality }\end{array}$ & $1995-2011$ & $\mathrm{CZ}, \mathrm{HU}, \mathrm{PL}$ & YES \\
\hline $\begin{array}{l}\text { Tomanová } \\
\text { (2016, pp. 273-285) }\end{array}$ & Jorion's model & $\begin{array}{l}2003-2006 \\
2007-2014 \\
\end{array}$ & $\mathrm{PL}$ & $6.7 \%$ and $27.3 \%$ of firms \\
\hline $\begin{array}{l}\text { Šimáková } \\
\text { (2017, pp. 2105-2111) }\end{array}$ & Jorion's model & $\begin{array}{l}2002-2008 \\
2008-2016\end{array}$ & $\begin{array}{c}\mathrm{CZ}, \mathrm{HU}, \mathrm{SK}, \\
\mathrm{PL} \\
\mathrm{CZ}, \mathrm{HU} \\
\mathrm{PL}, \mathrm{SK}\end{array}$ & $\begin{array}{l}\text { YES } \\
\text { NO } \\
\text { YES } \\
\text { NO }\end{array}$ \\
\hline
\end{tabular}

Source: own elaboration.

Stavárek and Tomanová (2014, pp. 882-890) examined exchange rate exposure on companies in the Czech Republic. The research period was 2003-2014 and their results, based on Jorion's model, show the statistically significant effect of the exchange rate on stock prices at the $5 \%$ level in the case of one firm. When using the $10 \%$ level of statistical significance, the results proved a relationship for five firms. Tomanová (2014, pp. 47-65) examined the foreign exchange exposure of 39 Hungarian publicly traded companies. The research period was 2000-2014. She used Jorion's model approach and proved a causal relationship for $18.4 \%$ of firms at the $10 \%$ statistical significance level in the period 2007-2014. Another study by Tomanová (2016, pp. 273-285) examined the effect of the exchange rate on stock prices on 35 Polish publicly traded companies. She proved a causal relationship for $27.3 \%$ of companies at the $10 \%$ statistical significance level in the period 2007-2014.

A paper by Šimáková (2017, pp. 2105-2111) applies Jorion's model and panel data regression for the sample period 2002-2016, which is also divided into pre-crisis and post-crisis parts. Estimations for the whole period revealed a negative relationship between the exchange rate and the value of stock companies in the case of the Czech Republic, Hungary and Slovakia. No effect of the exchange rate on the stock prices was proved for Poland. The highest exposure is observed in the case of Hungary and the Czech Republic. A positive tendency can be seen when comparing the pre-crisis and post-crisis periods. Except for Hungary, all markets showed decreased exchange rate exposure in time.

In summary, the results of the few previously published studies concerning the V4 countries indicate mixed results for evidence of a relationship between exchange rates 
and a company's value. They differ in the nature of the companies, industries, countries of estimation, sample period, or methodology used. Compared to those studies, this research uses the most recent available data at the firm level to avoid the aggregation bias problem which can influence the results. Furthermore, this paper takes into account the last financial crisis, which allows us to test the persistence of exchange rate exposure.

Economic theory also suggests the industrial sector's affiliation correlation with foreign exchange rate exposure (Marston 2001, p. 150). This assumption was confirmed by a few empirical studies, which show that foreign exchange exposure is significantly different across different industries. Bodnar et al. (2002, p. 229) argue for a company's exposure as a dependent variable of its ability to pass on increased expenses or prices caused by exchange rate development to the consumers. As Ampomah et al. (2013, p. 255) say, it depends on industry competitiveness, which determines the price elasticity of demand and the degree of substitutability of the goods. The exposure coefficient can suffer from measurement biases. Therefore, grouping firms by certain characteristics, notably industry sector, can lead to a less noisy estimate of their currency exposure. Therefore, this paper focuses only on one industry. Hence, this study substantially contributes to the scientific discussion in this field and fills the gap in the literature about the exchange rate exposure of companies operating in the chemical industry of the V4 countries.

\section{Methodology and Data}

Adler and Dumas (1984, p. 41) state that the exchange rate exposure of a company is a regression coefficient. This assumption is followed by Jorion (1990, pp. 331-345), whose pilot study explains changes in stock prices by changes in the market index and exchange rates. The market approach for foreign exchange exposure identification based on Jorion (1990, pp. 331-345) has continually been used with various modifications, according to the methodological development, by applying it to various geographic areas and data samples. It is a two-factor model, where the return on the market index is the first factor and the exchange rate change is the second factor. The exchange rate and the market index represent the independent variables. The model is formed into the equation as follows:

$$
R_{i t}=\alpha_{i}+\beta_{i} R M_{t}+\delta_{i} R F X_{t}+\varepsilon_{i t}
$$

where $\alpha_{i}$ is the constant term, $R_{i t}$ is the stock price return of company $i$ in time period $t, R M_{t}$ is the return of the market index, $\beta_{i}$ is the company's market beta, and $R F X_{t}$ is the relevant exchange rate. Hence, coefficient $\delta_{i}$ reflects the change in the stock price returns that can be explained by movements of the exchange rate on the market return. 
Existing studies on the determinants of a company's exposure to exchange rate movements tend to use cross-sectional analysis, which ignores the temporal dimension of both the dependent and explanatory variables. Therefore, this study uses not only the classic OLS method but also the panel data approach, which pools data across companies and time in order to improve estimation efficiency. This can avoid the risk of choosing an unrepresentative year and helps to monitor unobservable individual effects. Panel regression can provide additional insight into the tested relationships. To determine dataset effects as random or fixed, we use the Breusch-Pagan Langrage multiplier test.

$$
L M=\frac{n T}{2(T-1)}\left[\frac{\sum_{i=1}^{n}\left(\sum_{t=1}^{T} e_{n}\right)^{2}}{\sum_{i=1}^{n} \sum_{t=1}^{T} e_{i t}^{2}}-1\right]^{2}
$$

where $T$ is the length of the time series, $n$ is the number of units in the cross-sectional dimension, and $e_{i t}$ is a residual term.

The time series used for the estimation is on a monthly frequency. Real effective exchange rate indices (REER) are used as variables REX and are obtained from the Eurostat database. REER represents the trade-weighted average of a country's currency relative to the basket of other major currencies, adjusted for the effects of inflation. Deflators for computing REER are consumer price indices and trade-weighting is based on 18 major trading partners of each tested country. Data of market indices are obtained from the OECD statistical database and data of the stock prices of the selected companies are obtained from the Investing.com database.

The sample period for the estimation covers the period from September 2003 to June 2016. This period covers data after the transformation period; thus, the capital markets are based more on market rules without significant market deformation. The analysis involves stock companies listed on the official stock exchanges in the V4 countries. The selection was based on the market share and data availability for the selected companies. The selected companies with their basic characteristics can be seen in Table 2.

The selected companies are quoted on the major V4 stock exchanges, and all are from the chemical industry, namely the petrochemical and pharmaceutical industries. The same industry was chosen for a possible comparison of the results across the V4 countries. Furthermore, the chemical industry represents a significant industry for all V4 economies. In the Czech Republic, the chemical industry is the third largest industrial sector, in Slovakia, it is the fourth largest industry, and in Hungary, it is the fifth largest sector and covers $17 \%$ of all industrial exports. In Poland, the chemical industry is the second most important production industry. The importance of the selected companies can also be seen from their market capitalization and shares on their respective official market index. 
The Role of Exchange Rates in the Stock Price Development of Chemical Companies...

Table 2. Basic Characteristics of the Selected Stock Companies in 2017

\begin{tabular}{|c|c|c|c|}
\hline Industry & Company & Market capitalization (EUR) & \% of market index \\
\hline \multirow{4}{*}{ Petrochemical } & UNIPETROL (CZ) & $1,466,380,459$ & 2.98 \\
\cline { 2 - 4 } & MOL(HU) & $6,878,831,928$ & 31.13 \\
\cline { 2 - 4 } & PKN ORLEN (PL) & $7,022,066,065$ & 9.59 \\
\cline { 2 - 4 } & SLOVNAFT (SK) & $1,600,000,000$ & 20.86 \\
\hline \multirow{4}{*}{ Pharmaceutical } & ZENTIVA* (CZ) & - & - \\
\cline { 2 - 4 } & RICHTER GEDEON (HU) & $3,844,051,426$ & 17.38 \\
\cline { 2 - 4 } & PELION (PL) & $960,556,845$ & 0.13 \\
\cline { 2 - 4 } & BIOTIKA (SK) & $22,600,000$ & 11.88 \\
\hline
\end{tabular}

* listed on the Prague Stock Exchange only until 04/2009

Source: own elaboration.

UNIPETROL was selected as a representative of the petrochemical companies in the Czech Republic, as it is the leading refining and petrochemical company there. In the Czech Republic, it is one of the largest oil processors, one of the most important plastics manufacturers, and the owner of the largest network of petrol stations. MOL is a Hungarian oil and petrochemical group which produces an entire portfolio of petroleum products, provides transportation, and operates a network of petrol stations. $45 \%$ of the company's production is exported to European markets. PKN ORLEN S.A. is a Polish petrochemical company listed on the Warsaw Stock Exchange, which is the largest not only in Poland but also throughout the V4 countries. It exports to more than 50 world markets, and like the previous petrochemical industries, it also generates cash flow in foreign currencies. The largest part of the sales of the petrochemical industry in Slovakia is formed by SLOVNAFT. It deals with petroleum processing, storage, distribution, and the wholesale of petroleum products. According to the annual reports of all selected petrochemical companies, they could be exposed to currency risk mainly due to a significant share of liabilities and trade receivables in foreign currencies. These companies tend to decrease potential currency risk losses by natural hedging and use hedging tools such as forwards and currency swaps.

Figure 1 shows that stock prices in the pre-crisis period grew in the case of UNIPETROL and MOL. The stocks of ORLEN and SLOVNAFT show a stagnating trend before the crisis. All stocks sharply declined in the financial crisis period. After the crisis, a market revival was detected. The exception was SLOVNAFT, whose stocks continued to decline.

ZENTIVA is an international pharmaceutical company engaged in the manufacture of medicinal products. Since 2009, the company has been part of the Sanofi Group. Therefore, this company was listed on the Prague Stock Exchange only between June 2004 and April 2009. Due to the fact that there is no other company listed on this stock exchange that could be included in the analysis of this sector, ZENTIVA was selected as a representative of the pharmaceutical industry in the Czech Republic. A substantial part of the company's sales is in the euro currency, which they also use as a billing currency. However, they also operate in developed 
markets and other countries. For this reason, the company's profit may be affected by fluctuations in foreign exchange rates. RICHTER GEDEON was chosen for the analysis of the pharmaceutical industry in Hungary. This company is engaged in the research, development, production, sale, and marketing of pharmaceutical products. The company holds a strong position not only in Hungary but also in the countries of Central and Eastern Europe. Due to the composition of the company's income and expenditures, currency fluctuations might have a real effect on its value. PELION is the selected representative of the Polish pharmaceutical industry as it is the largest health care company in Poland. The representative of the pharmaceutical industry in Slovakia is BIOTIKA. This company produces a whole range of chemical substances for its contracting partners, including ones from abroad. None of the selected pharmaceutical companies automatically use hedging instruments. However, according to their annual reports, they actively monitor the development of the exchange rate, and they evaluate foreign exchange exposure. In the case of impending fluctuations, companies use forward contracts or swaps, but only in exceptional cases. Like the selected petrochemical companies, they try to achieve natural hedging.

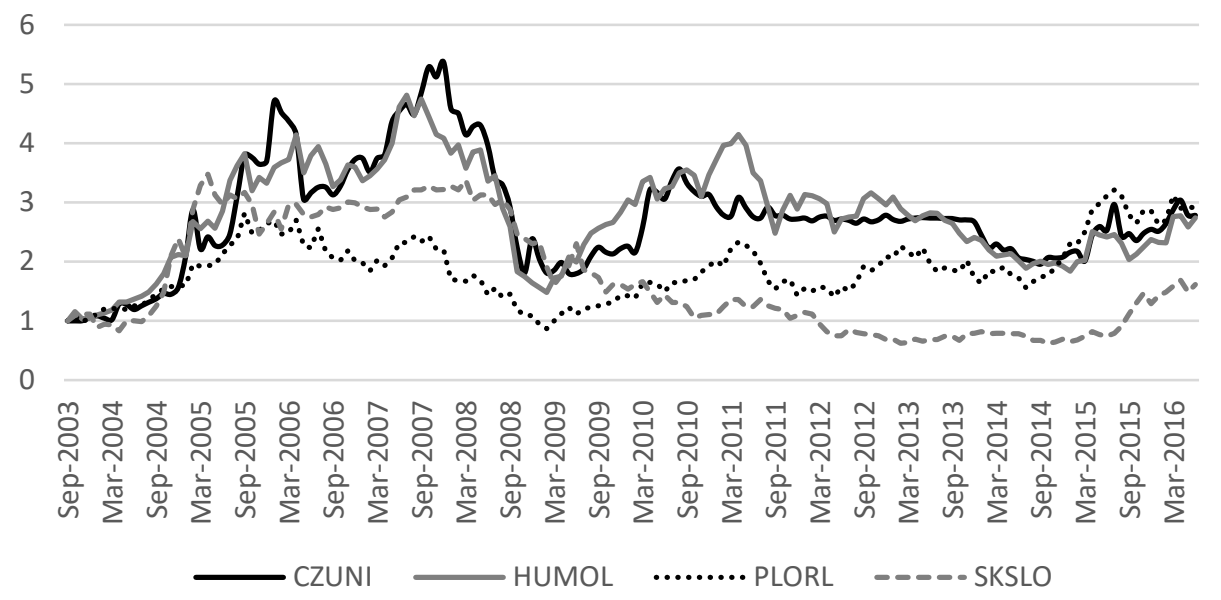

Figure 1. Stock Price Development of Selected Petrochemical Companies (index form) Source: own elaboration.

Figure 2 shows the stock price development of selected pharmaceutical companies listed on the V4 stock exchanges. The common, increasing trend of stock prices in the pre-crisis period can also be seen in the case of the petrochemical companies. Only the Slovak company, BIOTIKA, kept a relatively constant level during this period. In the post-crisis period, PELION and RICHTER GEDEON's stock prices were still around the same level, and Slovak BIOTIKA recorded stock price increases. In the most recent data, the stock prices of the Polish company PELION are falling, while shares of the Hungarian and Slovak companies show a growing trend. 
The Role of Exchange Rates in the Stock Price Development of Chemical Companies...

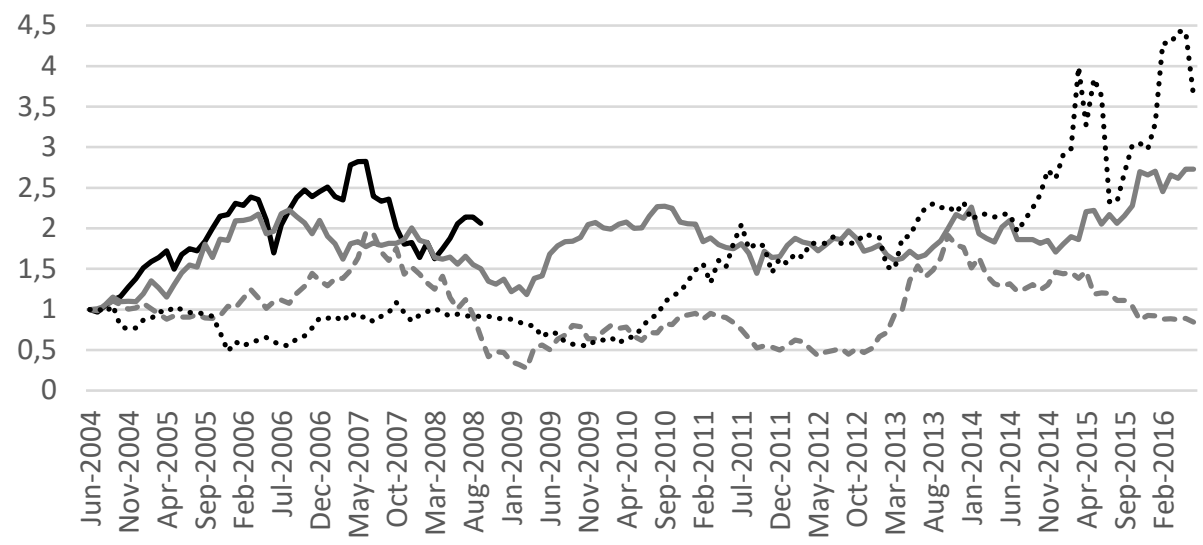

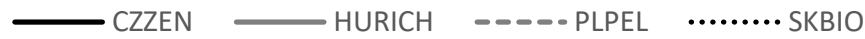

Figure 2. Stock price development of selected pharmaceutical companies (index form) Source: own elaboration.

\section{Results}

The individual companies' regressions were estimated for three periods: the whole sample (2003/09-2016/06), the pre-crisis period (2003/09-2008/09) and the post-crisis period (2008/10-2016/06). This splitting allows us to test the persistence of exchange rate exposure. The augmented Dickey-Fuller test (ADF) was used to test the stationarity of times series. Based on the ADF test, it was verified that all of the time series used are stationary on the first difference, which is the basic precondition for using OLS regression. The results of the Durbin-Watson autocorrelation test were close to 2 in all cases.

Table 3. Estimated Coefficients of Individual Regression Analysis

\begin{tabular}{|l|c|c|c|c|c|c|}
\hline \multirow{2}{*}{\multicolumn{1}{c|}{ Company }} & \multicolumn{2}{c|}{ Whole period } & \multicolumn{2}{c|}{ Pre-crisis period } & \multicolumn{2}{c|}{ Post-crisis period } \\
\cline { 2 - 7 } & $R M$ & $F X$ & $R M$ & $F X$ & $R M$ & $F X$ \\
\hline UNIPETROL (CZ) & $0.70^{\mathrm{a}}$ & 0.26 & $1.19^{\mathrm{a}}$ & 1.46 & $0.52^{\mathrm{a}}$ & 0.03 \\
\hline MOL(HU) & $0.91^{\mathrm{a}}$ & -0.18 & $1.08^{\mathrm{a}}$ & -0.32 & $0.82^{\mathrm{a}}$ & -0.06 \\
\hline PKN ORLEN (PL) & $0.79^{\mathrm{a}}$ & 0.22 & $0.76^{\mathrm{a}}$ & 0.13 & $0.80^{\mathrm{a}}$ & 0.30 \\
\hline SLOVNAFT (SK) & $1.13^{\mathrm{a}}$ & -0.48 & $1.13^{\mathrm{a}}$ & $-1.12^{\mathrm{c}}$ & $1.12^{\mathrm{a}}$ & 1.15 \\
\hline ZENTIVA $(\mathrm{CZ})$ & - & - & $0.70^{\mathrm{a}}$ & -0.00 & - & - \\
\hline RICHTER GEDEON (HU) & 0.65 & -0.39 & 0.73 & -0.62 & $0.60^{\mathrm{a}}$ & -0.22 \\
\hline PELION (PL) & $0.89^{\mathrm{a}}$ & $1.36^{\mathrm{b}}$ & $0.26^{\mathrm{c}}$ & 0.79 & $1.16^{\mathrm{a}}$ & $1.44^{\mathrm{c}}$ \\
\hline BIOTIKA (SK) & $0.33^{\mathrm{c}}$ & 0.77 & 0.17 & 1.56 & $0.66^{\mathrm{b}}$ & 0.78 \\
\hline
\end{tabular}

* listed on the Prague Stock Exchange only until 04/2009

Source: own elaboration. 
The results in Table 3 show that there is no statistically significant impact of exchange rates on stock prices for the petrochemical companies when analyzing the whole sample period. However, the impact of market indices on their share prices was demonstrated. The results for market indices were also similar for the pharmaceutical companies. Furthermore, a direct relationship was detected between the exchange rate and the share price in the case of the Polish company PELION, where this influence was demonstrated for the whole period, and in the post-crisis period, this effect seems to be even stronger. The results showed that the depreciation of the Polish zloty leads to increases in the share prices of this company. Depreciation of the Polish zloty seems to have a positive effect on the volume of the company's exports, which increases profit, and ultimately increases stock prices. Interesting results have been obtained for SLOVNAFT in the pre-crisis period, which could also be considered the pre-euro period in Slovakia. We can see that in this case, there was a statistically significant impact of exchange rate development on the stock price.

The results of the panel regression are presented in Table 4. Due to the fact that the period of listing ZENTIVA on the market is different in comparison to the other companies, the panel used for the regression testing the pharmaceutical companies is unbalanced. At a confidence level of $95 \%$, it is confirmed that the models are statistically significant. The coefficient of determination of the models also indicates that more than $40 \%$ of changes in stock return are explained by this model. The Breusch-Pagan Lagrange multiplier test revealed random effects in this case.

Table 4. Estimated Coefficients of the Panel Regression

\begin{tabular}{|l|c|c|c|c|c|c|}
\hline \multicolumn{1}{|c|}{ Industry } & \multicolumn{2}{c|}{ Whole period } & \multicolumn{2}{c|}{ Pre-crisis period } & \multicolumn{2}{c|}{ Post-crisis period } \\
\hline & $R M$ & $F X$ & $R M$ & $F X$ & $R M$ & $F X$ \\
\hline Petrochemical industry & $0.43^{\mathrm{a}}$ & $0.001^{\mathrm{a}}$ & $0.40^{\mathrm{a}}$ & $0.001^{\mathrm{b}}$ & $0.68^{\mathrm{a}}$ & 0.008 \\
\hline Pharmaceutical industry & $0.35^{\mathrm{a}}$ & $0.19^{\mathrm{a}}$ & $0.37^{\mathrm{a}}$ & $0.15^{\mathrm{b}}$ & $0.52^{\mathrm{b}}$ & 0.11 \\
\hline
\end{tabular}

* listed on the Prague Stock Exchange only until 04/2009 Source: own elaboration.

The tested petrochemical sector in the V4 countries is shown to be exposed to exchange rate risk at a significance level of $1 \%$ during the whole sample period. The positive exposure coefficient suggests that depreciation of the domestic currency is followed by an increase in the firm's stock returns. The results obtained from this paper are similar to those by Abbasi et al. (2015, pp. 1170-1179). However, this coefficient is almost zero, which could be caused by using natural hedging or other sophisticated instruments on the hedging markets. The comparison of the pre-crisis and post-crisis periods shows that a statistically significant relationship between exchange rate and stock price development is revealed only for the pre-crisis data sample. It could be caused by the adoption of the euro in Slovakia in January 2009 and by the interventions on the foreign exchange market provided by the Czech National Bank between November 2013 and April 2017. These factors could definitely decrease the exchange rates risk for the tested companies. 
In the case of the pharmaceutical industry, the coefficient of exchange rate exposure in the whole and in the pre-crisis period is higher than in the petrochemical sector. The fact is that foreign exchange risk strategy is different for the petrochemical and pharmaceutical companies. The petrochemical companies use automatic hedging tools against this risk. The pharmaceutical companies do not automatically use them; they only actively access the tools provided by regular monitoring of the development of the exchange rate. Therefore, it can be stated that in the case of petrochemicals, where the effect of the exchange rate on the share price is confirmed only partly in the case of panel regression, appropriate hedging instruments likely reduce foreign exchange exposure. This suggests that exchange rate risk could be eliminated by using hedging instruments.

\section{Conclusion}

The current situation of the international economic environment reopens the question about the effects of exchange rates on companies' values. The aim of the paper was to evaluate the effect of the exchange rates on the stock prices of companies in the chemical industry listed on the stock exchanges in the V4 countries. The paper applied Jorion's model for the sample period 2003-2016 while using individual OLS regressions and panel regressions. The study showed that there is no statistically significant impact of exchange rates on stock prices for individual petrochemical companies. However, the impact of market indices on their share prices was demonstrated. The results for market indices were also similar for the pharmaceutical companies. Furthermore, a direct relationship was detected between the exchange rate and the share price in the case of the Polish company PELION, where this influence was demonstrated for the whole period, and in the post-crisis period, this effect seems to be even stronger. The results showed that the depreciation of the Polish zloty leads to increases in the share prices of this company. Depreciation of the Polish zloty seems to have a positive effect on the volume of the company's exports, which increases profit, and ultimately increases stock prices.

The panel regression for the petrochemical sector in the V4 countries revealed exposure to the exchange rate risk level during the whole sample period and for the pre-crisis period. However, this coefficient is almost zero, which could be caused by using natural hedging or other sophisticated instruments on the hedging markets. In the case of the pharmaceutical industry, the coefficient of exchange rate exposure in the whole and in the pre-crisis period is higher than in the petrochemical sector. The lack of a significant relationship in the post-crisis period might have been caused by the adoption of the euro in Slovakia and by the interventions on the foreign exchange market provided by the Czech National Bank. These factors could definitely decrease the exchange rates risk for the tested companies.

The differences between the results for the petrochemical and pharmaceutical industries are likely to be affected by the hedging strategies in the tested companies. The 
petrochemical companies use automatic hedging tools against this risk, while the pharmaceutical companies do not; they only actively access the tools provided by regular monitoring of the development of the exchange rate. This indicates that exchange rate risk could be eliminated by the use of proper hedging instruments.

\section{References}

Abbasi, G.R., Mohammadi, H.M., Chaharded, O.M. (2015), The Study of the Effects of Exchange Rate Fluctuations on Petrochemical Industry Return in Tehran Stock Exchange, "European Online Journal of Natural and Social Sciences", Skripta s.r.o., Prague, Vol. 4, No. 1.

Adler, M., Dumas, B. (1984), Exposure to currency risk: Definition and measurement, "Financial Management", Wiley, Toronto, Vol. 13.

Akay, G.H., Cifter, A. (2014), Exchange rate exposure at the firm and industry levels: Evidence from Turkey, "Economic Modelling”, Elsevier, Oxford, Vol. 43.

Akel, G. (2014), Relationship between Exchange Rates and Stock Prices in Transition Economies Evidence from Linear and Nonlinear Causality Tests, [in:] Čermáková, K., Rotschedl, J. (eds.) 2nd Economics \& Finance Conference 2014, International Institute of Social and Economic Sciences, Vienna.

Ampomah, S.A., Mazouzub, K., Yinc, S. (2013), The foreign exchange exposure of UK non-financial firms: A comparison of market-based methodologies, "International Review of Financial Analysis", Elsevier, Oxford, Vol. 19.

Bodnar, G.M., Dumas, D., Marston, R.C. (2002), Pass-through and exposure, "Journal of Finance", Wiley, Danvers, Vol. 57, No. 1.

He, J., Ng, L.K. (1998), The Foreign Exchange Exposure of Japanese Multinational Corporations', "Journal of Finance", Wiley, Danvers, Vol. 53, No. 2.

Jorion, P. (1990), The exchange rate exposure of U.S. multinationals, "Journal of Business", The University of Chicago Press Journals, Chicago, Vol. 63, No. 3.

Marston, R.C. (2001), The effects of industry structure on economic exposure, "Journal of International Money and Finance”, Elsevier, Oxford, Vol. 20, No. 2.

Muller, A., Verschoor, W.F.C. (2006), Asymmetric foreign exchange exposure: Evidence from U.S. multinational firms, "Journal of Empirical Finance", Elsevier, Oxford, Vol. 13, No. 4-5.

Nieh, C., Wang, Y. (2005), ARDL approach to the exchange rate overshooting in Taiwan, "Review of Quantitative Finance and Accounting", Springer, New York City, Vol. 25.

Stavárek, D. (2005), Stock Prices and Exchange Rates in the EU and the USA: Evidence of their Mutual Interactions, "Czech Journal of Economics and Finance", Institute of Economic Studies, Prague, Vol. 55, No. 3-4.

Stavárek, D., Tomanová, L. (2014), Exchange Rate Volatility Exposure on Corporate Cash Flows and Stock Prices: The Case of Czech Republic, [in:] Tvrdoň, M., Majerová, I. (eds.), Proceeding of the $12^{\text {th }}$ International Scientific Conference on Economic Policy in the European Union Member Countries, Silesian University in Opava, School of Business Administration in Karviná, Karviná. 
Šimáková, J. (2017), The Impact of Exchange Rate Movements on Firm Value in Visegrad Countries, "Acta Universitatis Agriculturae et Silviculturae Mendelianae Brunensis", Mendel University in Brno, Brno, Vol. 65, No. 6.

Tomanová, L. (2014), Exchange Rate Exposure and its Determinants: Evidence on Hungarian Firms, "European Financial and Accounting Journal", University of Economics in Prague, Prague, Vol. 9, No. 2.

Tomanová, L. (2016), Exchange Rate Volatility Exposure on Corporate Cash Flows and Stock Prices: The Case of Poland, [in:] Bilgin, M.H., Danis, H., Demir, E., Can, U. (eds.), Proceeding of the $14^{\text {th }}$ Eurasia Business and Economics Society Conference on Business Challenges in the Changing Economic Landscape - Vol. 1, Springer International Publishing, Zurich.

\section{Streszczenie}

\section{Rola kursów wymiany w rozwoju cen akcji spółek chemicznych w państwach Grupy Wyszehradzkiej}

Celem artykułu jest ocena wpływu kursów walut na ceny akcji spółek z branży chemicznej notowanych na giełdach w krajach Grupy Wyszehradzkiej. Analiza empiryczna obejmowała okres od września 2003 r. do czerwca 2016 r. W oparciu o dane miesięczne pochcodzące z firm z branży petrochemicznej i farmaceutycznej dokonano analizy wpływu kursu wymiany na ceny akcji za pomocą modelu Joriona. W przeciwieństwie do wybranych spółek petrochemicznych, firmy farmaceutyczne nie stosowały żadnych instrumentów zabezpieczających w badanym okresie. Wpływ kursu walutowego na cenę akcji został udowodniony tylko w przypadku firm z branży farmaceutycznej. Sugeruje to, że ryzyko kursowe można wyeliminować za pomocą instrumentów zabezpieczających.

Słowa kluczowe: kurs walutowy, wartość firmy, ekspozycja na ryzyko walutowe, model Joriona, przemyst chemiczny 